\title{
BIOLOGI REPRODUKSI DAN GENETIK POPULASI IKAN KEMBUNG (Rastrelliger brachysoma, FAMILI SCOMBRIDAE) DI PANTAI UTARA JAWA
}

\author{
Achmad Zamroni1), Suwarso'), dan Nur Ainun Mukhlis'1) \\ 1)Peneliti pada Balai Riset Perikanan Laut, Muara Baru-Jakarta \\ Teregristrasi I tanggal: 30 Juli 2007; Diterima setelah perbaikan tanggal: 14 Nopember 2007; \\ Disetujui terbit tanggal: 3 April 2008
}

\begin{abstract}
ABSTRAK
Biologi reproduksi ikan dan genetik populasi merupakan hal yang penting dalam manajemen perikanan. Penelitian tentang ikan kembung (Rastrelliger brachysoma) dilakukan berdasarkan pada pengamatan secara visual terhadap gonad dan mengukur indeks gonad. Contoh genetik ikan kembung (Rastrelliger brachysoma) diperoleh dari 5 lokasi penangkapan, yaitu perairan utara Jakarta, Eretan Wetan (Indramayu), Pekalongan, Rembang, dan Pasuruan (Selat Madura). Analisis restriction fragment length polymorphism mitochondria-DNA ikan contoh menggunakan 5 jenis enzim restriksi yaitu Alu I, Hae III, Nde II, Taq I, dan Hind III. Hasil pengamatan terhadap 1.024 spesimen ikan menunjukkan bahwa ikan contoh dominan dalam keadaan belum matang (tingkat kematangan gonad I, II, dan III). Dugaan musim pemijahan ikan kembung (Rastrelliger brachysoma) terjadi pada musim timur karena nilai indeks gonad pada musim timur rendah. Ukuran ikan yang matang (tingkat kematangan gonad IV) berkisar antara 19 sampai dengan $20 \mathrm{~cm}$ (FL) dengan nilai indeks gonad 0,49 sampai dengan 6,98 . Hasil analisis restriction fragment length polymorphism mitochondria-DNA menunjukkan pola pemotongan yang diperoleh adalah sama (satu pola pemotongan) sehingga secara genotip ikan contoh yang diamati tidak terdapat perbedaan yang nyata.
\end{abstract}

KATAKUNCI: ikan kembung (Rastrelliger brachysoma), biologi reproduksi, indeks gonad, genetik populasi, restriction fragment length polymorphism mitochondria-DNA

ABSTRACT: Reproductive biology and genetic population of Short mackerel (Rastrelliger brachysoma, Scombridae) in the coastal water of northern Java. By: Achmad Zamroni, Suwarso, and Nur Ainun Mukhlis

Reproductive biology and population genetic of fish provide the important point in the fisheries management. A study on short mackerel (Rastrelliger brachysoma) was based on visual observations to the ovary and the measurement of gonado somatic index. Genetic sample of short mackerel (Rastrelliger brachysoma) were collected from 5 catch location i.e. northern Jakarta, Eretan Wetan (Indramayu), Pekalongan, Rembang, and Pasuruan (Madura Strait). Analysis restriction fragment length polymorphism mitochondria-DNA were used 5 kind restriction enzyme Alu I, Hae III, Nde II, Taq I, and Hind III. Observations on 1,024 specimen showed that the sample was dominated in immature stage (stage I, II, and III). Spawning season of short mackerel (Rastrelliger brachysoma) was supposed in the east wind due to the fact that gonado somatic index is lower in east wind season. The size of ripe (stage IV) specimen was about 19 to $20 \mathrm{~cm}$ fork length, with gonado somatic index value range from 0.49 to 6.98 . The result of analysis restriction fragment length polymorphism mitochondria-DNA showed has the same digestion model (one digestion model) therefore no significant differences in fish sample gonotip.

KEYWORDS: $\quad$ short mackerel (Rastrelliger brachysoma), reproductive biology, gonado somatic index, genetic population, restriction fragment length polymorphism mitochondriaDNA

\section{PENDAHULUAN}

Ikan kembung (Rastrelliger brachysoma) termasuk jenis ikan pelagis kecil yang hidup di perairan pantai (neritik), serta tersebar hampir di sepanjang pantai utara Jawa, Selat Madura, pantai barat Sumatera Selatan, dan pantai selatan Kalimantan (Ketapang, Kota Baru). Keberadaan ikan kembung (Rastrelliger brachysoma) pada umumnya diikuti eksploitasi oleh pukat cincin mini (mini purse seine) yang hanya aktif melakukan penangkapan di perairan pantai dengan operasional hanya 1 hari (perikanan skala kecil). Tipe armada penangkap pukat cincin mini terutama berasal dari Jawa Timur dan Brebes. Data pendaratan menunjukkan di Pekalongan didaratkan 310 ton atau sekitar $15 \%$ dari seluruh pendaratan oleh pukat cincin mini (Suwarso et al., 2007).

Seperti layaknya perikanan skala kecil pada umumnya, eksploitasi oleh pukat cincin mini telah 


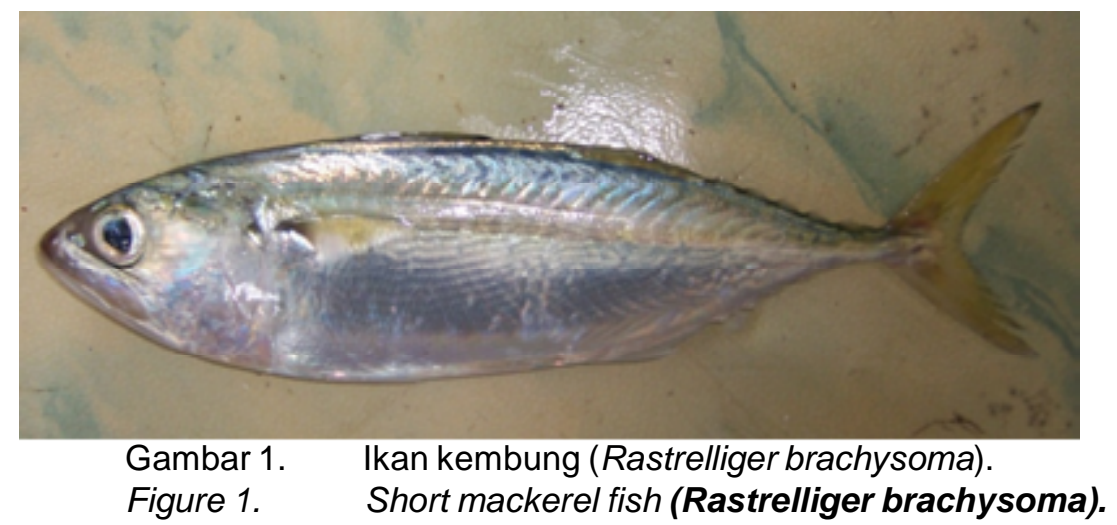

mengakibatkan tekanan penangkapan tinggi hampir di seluruh wilayah (Nurhakim et al., 1995), karena jenis ikan kembung (Rastrelliger brachysoma) menjadi sasaran utama penangkapan perikanan tersebut. Penangkapan dilakukan melalui cara berburu (hunting), tanpa bantuan rumpon ataupun lampu sehingga aktivitas pada sekitar gelap bulan, yaitu sekitar seminggu setelah terang bulan dan berhenti seminggu menjelang terang bulan berikut. Perilaku migrasi ikan tersebut diperkirakan mempengaruhi pola migrasi kapal pukat cincin mini di pantai utara Jawa.

Informasi mengenai biologi reproduksi dan unit biologi (unit stok, sub populasi) sangat penting sebagai landasan kuat bagi pengelolaan perikanan berbasis stok. Dalam konteks penyebaran dan kelimpahan populasi, stok ikan pelagis memanfaatkan fenomena perubahan hidrografis sebagai bagian dari siklus migrasi dan sejarah hidup (life history), informasi biologi reproduksi sangat menentukan dalam pengelolaan sumber daya bagi wilayah perairan padat tangkap dan pengembangan perikanan bagi wilayahwilayah yang rendah tingkat penangkapan. Masalah ekologis yang berkaitan dengan unit populasi ikan pelagis akibat aktivitas migrasi dan filogenetik memerlukan suatu pemecahan, antara lain dengan melakukan identifikasi stok secara genetik. Identifikasi stok tidak hanya berfungsi untuk mengetahui karakter dan asal-usul stok, tetapi dapat pula dipergunakan dalam pengaturan operasi penangkapan ikan, terutama jika aktivitas migrasi ikan tersebut meliputi antar negara. Menurut Yusron (2005), keragaman genetik suatu populasi memiliki arti penting, karena faktor yang mempengaruhi respon suatu populasi terhadap seleksi alam maupun buatan yang dilakukan oleh manusia untuk mengeksploitasi sumber daya hayati laut tersebut sesuai kebutuhan. Penelitian sebelumnya mengenai struktur populasi dan stok ikan kembung (Rastrelliger brachysoma) di Indonesia dilakukan oleh Sujastani (1976) dengan menggunakan metode morfometrik. Hasil dari penelitian tersebut menunjukkan bahwa ikan kembung (Rastrelliger brachysoma) di pantai utara Jawa tidak terdapat perbedaan yang cukup signifikan. Oleh karena itu, perlu dilakukan studi atau penelitian mengenai struktur populasi ikan yang berbasis keragaman genetik dari beberapa wilayah geografis.

Variasi genetik dapat dievaluasi dengan 2 cara yaitu dengan allelic diversity dan heterozygosity. Beberapa metode dapat digunakan untuk mengestimasi tingkat variasi genetik yaitu menggunakan molecular marker (Carvalho \& Pitcher, 1995) termasuk antara lain mitochodrial-DNA (Martin et al., 1992; Park \& Moran, 1995). Pengamatan secara langsung variasi DNA ditemukan bersama dengan isolasi tentang enzim restriksi. Penerapan langsung teknik molecular marker diawali dengan mitochodrial-DNA. Teknik molecular marker dapat dilakukan dengan menggunakan contoh dalam keadaan segar, beku, ataupun yang disimpan dalam alkohol (Ward \& Grewe, 1995; Nugroho et al., 1997).

Tulisan ini membahas tentang beberapa aspek biologi reproduksi ikan kembung (Rastreliger brachysoma) di pantai utara Pekalongan dan struktur genetik populasi di pantai utara Jawa dan Selat Madura, yang diharapkan dapat memberikan kontribusi sebagai bahan masukkan bagi pengelolaan sumber daya yang tepat dan bertanggungjawab dalam kontek sustainable fishery dan biodiversity di Laut Jawa.

\section{BAHAN DAN METODE}

Ikan contoh untuk studi reproduksi dikumpulkan dari hasil tangkapan pukat cincin mini Jawa Timur selama bulan April 2005 sampai dengan Mei 2006 di Pelabuhan Perikanan Nusantara Pekalongan, Jawa Tengah. Pengambilan contoh dilakukan secara acak melalui pengukuran sistimatis dengan mengikuti standar prosedur pengambilan contoh dan pengukuran seperti dikatakan oleh Potier \& Sadhotomo (1991). 
Karakter biologi yang diukur meliputi panjang cagak (fork length) dalam satuan $\mathrm{cm}$, bobot tubuh $(\mathrm{g})$, jenis kelamin (sex), tingkat kematangan gonad, dan bobot gonad segar $(\mathrm{g})$. Pengukuran karakter biologi dimulai pada ukuran $14 \mathrm{~cm}$ FL. Tingkat kematangan gonad (ovarium dan testis) ditentukan secara visual berdasarkan pada 5 skala kematangan gonad menurut Holden \& Raitt (1974) sebagai berikut tingkat kematangan gonad I (immature), tingkat kematangan gonad II (maturing), tingkat kematangan gonad III (ripening), tingkat kematangan gonad IV (ripe), dan tingkat kematangan gonad $\mathrm{V}$ (spent). Validasi tingkat kematangan gonad dilakukan berdasarkan pada hasil preparasi terhadap beberapa contoh gonad (ovary) yang terkumpul. Dugaan musim pemijahan didasarkan pada pola fluktuasi gonad somatic index; nilai gonad somatic index dihitung sebagai berikut:

$\mathrm{GSI}=(\mathrm{Wg} / \mathrm{BW}) \times 100 \%$

di mana:

$\mathrm{Wg}=$ bobot gonad (ovary/testis) segar

$\mathrm{BW}=$ bobot tubuh ikan

Analisis statistik dan grafis diterapkan untuk melihat kecenderungan yang terjadi dalam skala musim maupun ruang.

Contoh jaringan (daging) ikan untuk studi genetik diperoleh dari 5 lokasi penangkapan di kawasan pantai, yaitu perairan utara Jakarta, Eretan Wetan (Indramayu), Pekalongan, Rembang, dan Pasuruan (Selat Madura). Contoh jaringan yang dianalisis untuk masing-masing lokasi 10 spesimen daging dari 10 individu ikan yang dipilih secara acak. Analisis restriction fragment length polymorphism diterapkan terhadap genom DNA-mitochondria yang diperoleh melalui ekstraksi dan proses amplifikasi dengan menggunakan alat polymerase chain reaction dan kemudian proses restriksi dengan menggunakan 5 jenis enzym restriksi, yaitu Alu I, Hae III, Nde II, Taq I, dan Hind III (Gambar 2). Tahapan prosedur selengkapnya diuraikan berikut ini.

DNA ikan diekstraksi dari jaringan daging sebagai berikut potongan daging dimasukkan ke dalam tabung $1,5 \mathrm{ml}$ yang telah berisi $500 \mu \mathrm{l}$ larutan urea. Kemudian ditambahkan $20 \mu \mathrm{g}$ per $\mathrm{ml}$ protein kinase dan diinkubasi pada suhu $37^{\circ} \mathrm{C}$ selama 24 jam. Setelah itu, ditambahkan $1.000 \mu \mathrm{l}$ phenol chloroform isoamyl alcohol. Kemudian disentrifuge dengan kecepatan
10.000 rpm selama 10 menit. Lapisan supernatan diambil dan dimasukkan ke dalam tabung baru dan ditambahkan $10 \mu \mathrm{l} \mathrm{NH}_{3} \mathrm{COONa}$ dan $1.000 \mu \mathrm{l}$ Etanol $90 \%$. DNA diendapkan dengan mensentrifuge campuran tersebut pada kecepatan 10.000 rpm selama 10 menit, kemudian larutan di atas dibuang dan DNA dikeringkan pada suhu ruangan. Kemudian ditambahkan $100 \mu$ rehydration solution.

Primer yang digunakan untuk mengamplifikasi sekuense mitokondria D-loop adalah primer 16A dan 16B. Amplifikasi dilakukan dengan menggunakan mesin polymerize chain reaction. Cycle polymerize chain reaction yang digunakan dalam amplifikasi adalah satu siklus denaturasi pada suhu $95^{\circ} \mathrm{C}$ selama 2 menit. 35 siklus penggandaan yang terdiri atas $95^{\circ} \mathrm{C}$ selama 1 menit, $45^{\circ} \mathrm{C}$ selama 1 menit dan $72^{\circ} \mathrm{C}$ selama 2,5 menit. Selanjutnya, 1 siklus terakhir pada suhu $72^{\circ} \mathrm{C}$ selama 5 menit. Sekuense mitochodrialDNA yang didapat direstriksi dengan menggunakan endonuklease (enzim restriksi) sesuai dengan prosedur standar. Hasil restriksi kemudian dipisahkan secara elektroforesis dengan menggunakan gel agarose dalam Tris-Boric-EDTA buffer dan diamati dalam UV illuminator serta difoto.

\section{HASIL DAN BAHASAN}

\section{Biologi Reproduksi}

\section{Sebaran ukuran ikan contoh dan sex rasio}

Ukuran ikan contoh tersebar antara 14 sampai dengan $21 \mathrm{~cm}$ (FL) di mana sebagian besar ikan berukuran 15 sampai dengan $17 \mathrm{~cm}$. Jumlah ikan yang diamati 1.024 ekor, 491 ekor (48\%) berjenis kelamin jantan 533 ekor (52\%) berjenis kelamin betina. Rasio kelamin ikan jantan dan ikan betina (1:1.086) dengan uji statistik adalah sama atau seimbang (Gambar 3a). Ikan kembung jantan(Rastrelliger brachysoma) ternyata lebih banyak ditemukan pada ukuran lebih kecil (14 sampai dengan $16 \mathrm{~cm}$ ), sedangkan ikan betina lebih banyak ditemukan pada kisaran yang lebih besar (17 sampai dengan $20 \mathrm{~cm}$ ) (Gambar 3b). Ikan betina lebih banyak tertangkap pada bulan Maret, Mei, Juni, Juli, dan September. Hasil tangkapan ikan betina yang tertinggi terjadi pada bulan Mei, yaitu sekitar $80 \%$ dari ikan Jantan. Sedangkan untuk ikan jantan banyak tertangkap pada bulan April, Agustus, Oktober, dan Nopember. 


\section{Jaringan Ikan}

\section{daging bagian punggung}

\section{Ekstraksi}

menggunakan protein kinase dan $\mathrm{PCl}$ (Phenol Chloroform Isoamyl alcohol

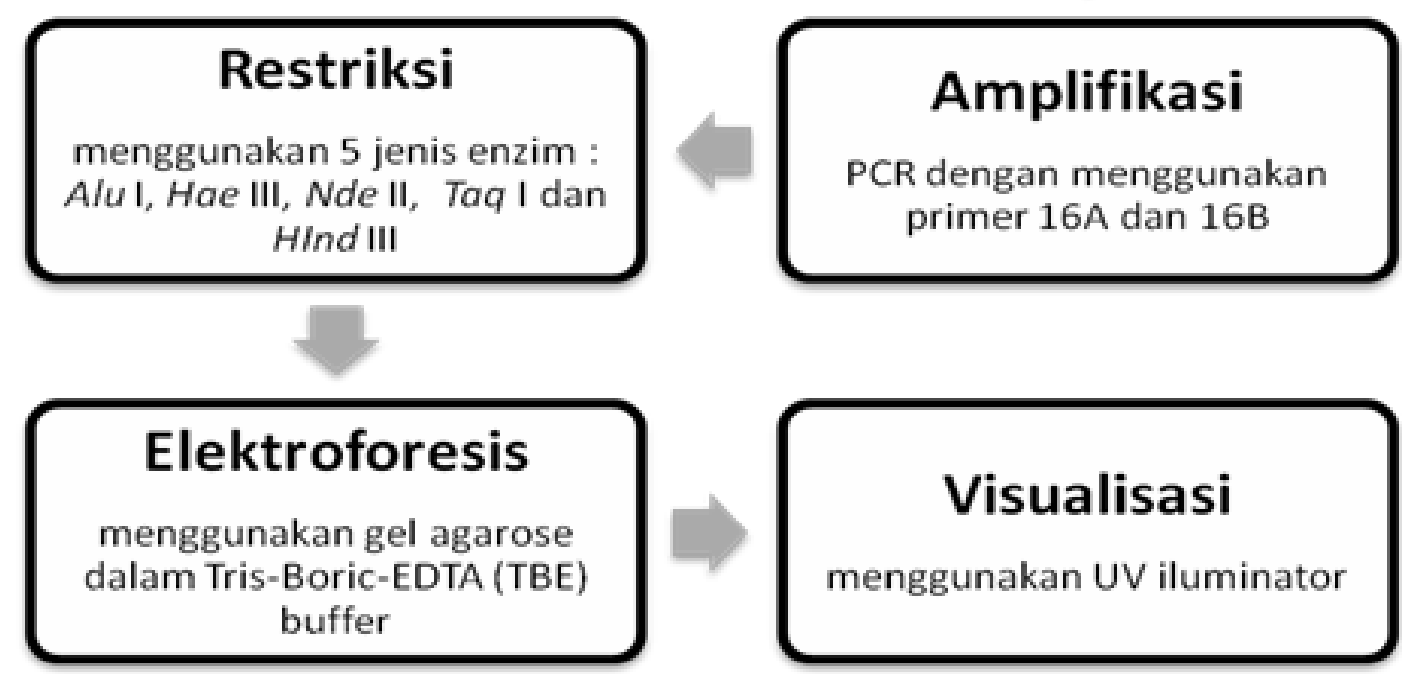

Gambar 2. Bagan prosedur dalam analisis restriction fragment length polymorphism terhadap genom mitochodrial-DNA ikan kembung (Rastrelliger brachysoma).

Figure 2. Analysis procedure restriction fragment length polymorphism for mitochodrial-DNA of Short mackerel fish (Rastrelliger brachysoma).

\section{Perkembangan Kematangan Gonad}

Dari contoh-contoh ovary yang diperoleh selama penelitian menunjukkan bahwa ikan yang tertangkap di daerah penangkapan pada umumnya berada dalam kondisi belum matang dan didominasi oleh tingkat kematangan gonad I, II, dan III, yaitu $91 \%$. Individu ikan matang gonad (ripe ovary, tingkat kematangan gonad IV) ditemukan 82 spesimen atau hanya sekitar $8 \%$ dari seluruh spesimen. Sedangkan spesimen dalam kondisi mijah (spent, tingkat kematangan gonad $\mathrm{V}$ ) hanya ditemukan $1 \%$ dari seluruh spesimen. Spesimen ripe ovary merupakan telur-telur matang yang akan segera dipijahkan. Deskripsi visual dari masing-masing tingkat kematangan gonad diperlihatkan pada lampiran.

Secara histologis, dalam spesimen gonad tingkat III (maturing) dapat dijumpai 2 kelompok utama pertumbuhan oocyte, yaitu oocyte tingkat previtellogenic dan oocyte dalam tingkat vitellogenesis yang dapat dibedakan 3 macam, yaitu yolk precursor 1, yolk precursor 2, dan yolk stage (red staining yolk). Sedangkan dalam ripe ovary, selain tingkat-tingkat oocyte seperti tersebut di atas juga dapat ditemukan oocyte yang matang (ripe) yang telah berkembang sempurna dengan ukuran paling besar dan translucent. Proporsi dari setiap tingkat pertumbuhan oocyte dalam suatu tingkat kematangan ovary atau gonad dipresentasikan dalam Tabel 1.

Ikan kembung (Rastrelliger brachysoma) yang tertangkap pada umumnya memiliki tingkat kematangan gonad II dan III, dan ukuran yang dominan tertangkap terdapat pada kisaran 15 sampai dengan $16 \mathrm{~cm}$. Ikan yang memiliki kematangan gonad tingkat I dan II berukuran lebih kecil (14 sampai dengan 16 $\mathrm{cm}$ ), sedangkan ikan-ikan yang lebih matang pada umumnya ditemukan pada ikan yang berukuran lebih besar $(>16 \mathrm{~cm})$. Hal tersebut, menunjukkan bahwa tingkat kematangan gonad ikan mengikuti atau selaras dengan ukuran ikan (selaras dengan pertumbuhan ikan). Gambar 5 memperlihatkan komposisi tingkat kematangan gonad ikan betina menurut ukuran ikan; dapat diduga bahwa ukuran reproduktif ikan kembung betina kemungkinan antara 16 sampai dengan $18 \mathrm{~cm}$ $\mathrm{FL}$, terlihat dari kontribusi tingkat kematangan gonad III yang paling besar. 

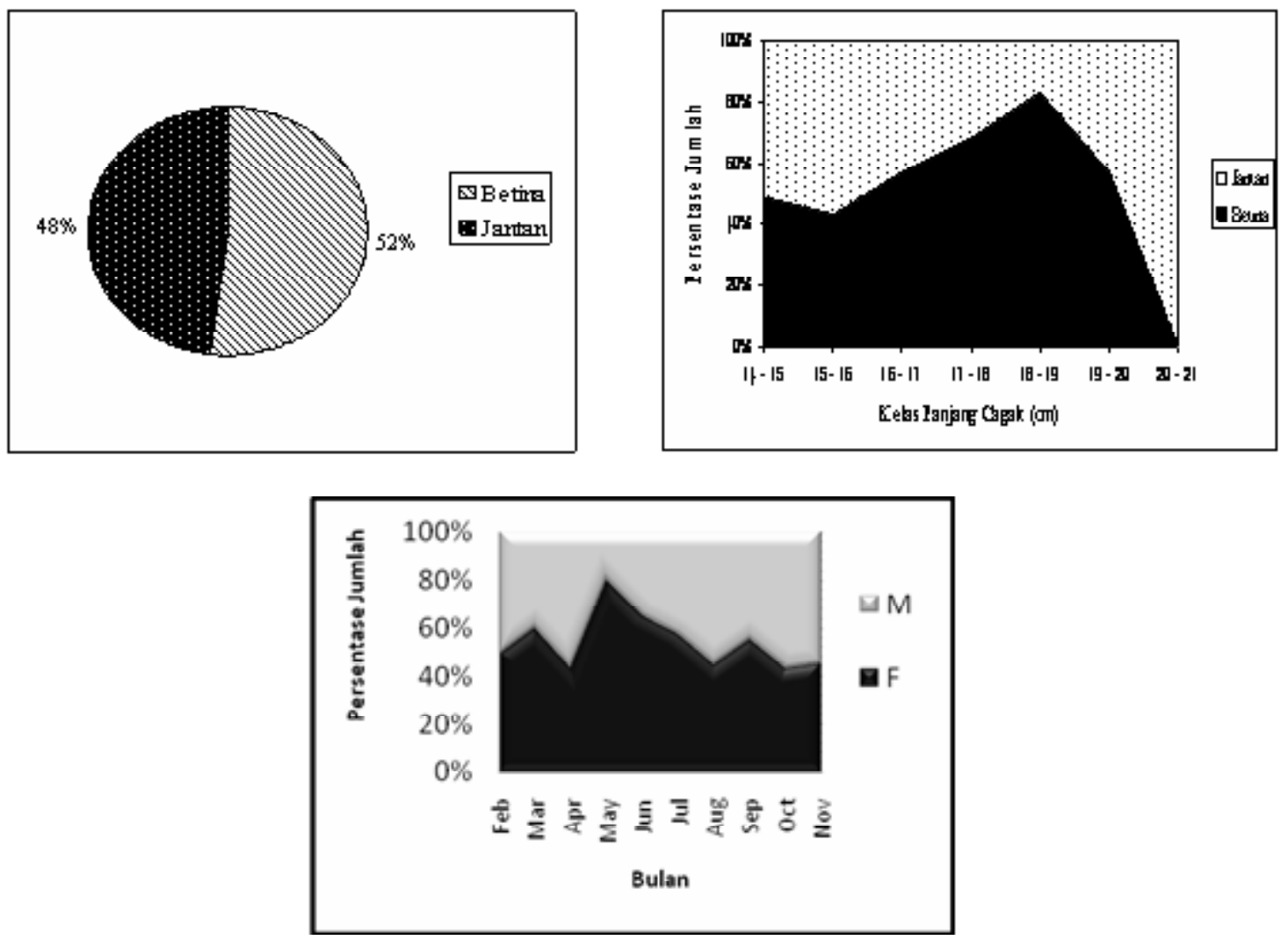

Gambar 3. Perbandingan kelamin (sex ratio jantan dan betina) ikan kembung (Rastrelliger brachysoma) di pantai utara Pekalongan (a), sex ratio menurut ukuran (b), dan sex ratio berdasarkan pada waktu (bulan) (c).

Figure 3. Sex ratio of short mackerel fish (Rastrelliger brachysoma) in coastal water of northern Pekalongan (a), sex ratio by size (b), and sex ratio by time (month) (c).

\section{Indeks Gonad}

Indeks gonad atau gonado somatic index, merupakan suatu indeks kuantitatif yang menunjukkan suatu kondisi kematangan seksual ikan. Pada umumnya semakin panjang tubuh ikan, maka semakin besar pula nilai gonado somatic index yang diperoleh sehingga ovarium yang lebih matang memiliki bobot dan ukuran lebih besar, termasuk penambahan dari ukuran telur. Dari hasil pengukuran diperoleh gonado somatic index ikan kembung betina (Rastrelliger brachysoma) berkisar antara 0,13 sampai dengan 11,24; yang dapat dipisah menurut tingkat kematangan sexual tingkat kematangan gonad I memiliki nilai gonado somatic index antara 0,11 sampai dengan 2,69 , tingkat kematangan gonad II memiliki antara 0,28 sampai dengan 4,75, tingkat kematangan gonad III antara 0,59 sampai dengan 7,19; dan tingkat kematangan gonad IV antara 2,59 sampai dengan 11,24 , sedangkan tingkat kematangan gonad $\mathrm{V}$ nilai gonado somatic index berkisar antara 0,53 sampai dengan 7,73 (Gambar 6a).
Secara umum, gonado somatic index maksimum diperoleh dari spesimen dengan bobot gonad yang maksimum pula. Pada Gambar $6 \mathrm{~b}$ diketahui bahwa rata-rata gonado somatic index tertinggi didapatkan pada spesimen dengan ukuran 19 sampai dengan 20 $\mathrm{cm}$ FL. Ikan yang berukuran di bawah $19 \mathrm{~cm}$ pada umumnya ikan belum matang, sehingga nilai ratarata gonado somatic index rendah (Gambar 6b). Diagram scatter nilai gonado somatic index menurut ukuran dari setiap tingkat kematangan diperlihatkan pada Gambar 7.

Spesimen yang ditemukan dalam kondisi matang tidak selalu memiliki nilai gonado somatic index yang maksimum, karena diduga terjadi proses pematangan yang lebih cepat pada telur walaupun ovarium belum tumbuh dengan sempurna. Nilai gonado somatic index dari ikan-ikan yang matang tersebut berkisar antara 0,49 sampai dengan 6,98 dengan nilai rata-rata 3,42 (Gambar 7). Pada Gambar 6a menunjukkan bahwa semakin tinggi tingkat kematangan gonad ikan, semakin tinggi pula nilai gonado somatic index yang 
diperoleh, karena dengan meningkat nilai tingkat kematangan gonad, maka diikuti pula dengan meningkat bobot gonad sehingga dapat meningkatkan bobot tubuh. Terjadi pengecualian untuk tingkat kematangan gonad $\mathrm{V}$, nilai rata-rata gonado somatic index cenderung sama dengan nilai pada tingkat kematangan gonad IV, karena pada tingkat kematangan gonad $\mathrm{V}$ sebagian telur telah dikeluarkan pada saat pemijahan, sehingga bobot gonad cenderung menurun.

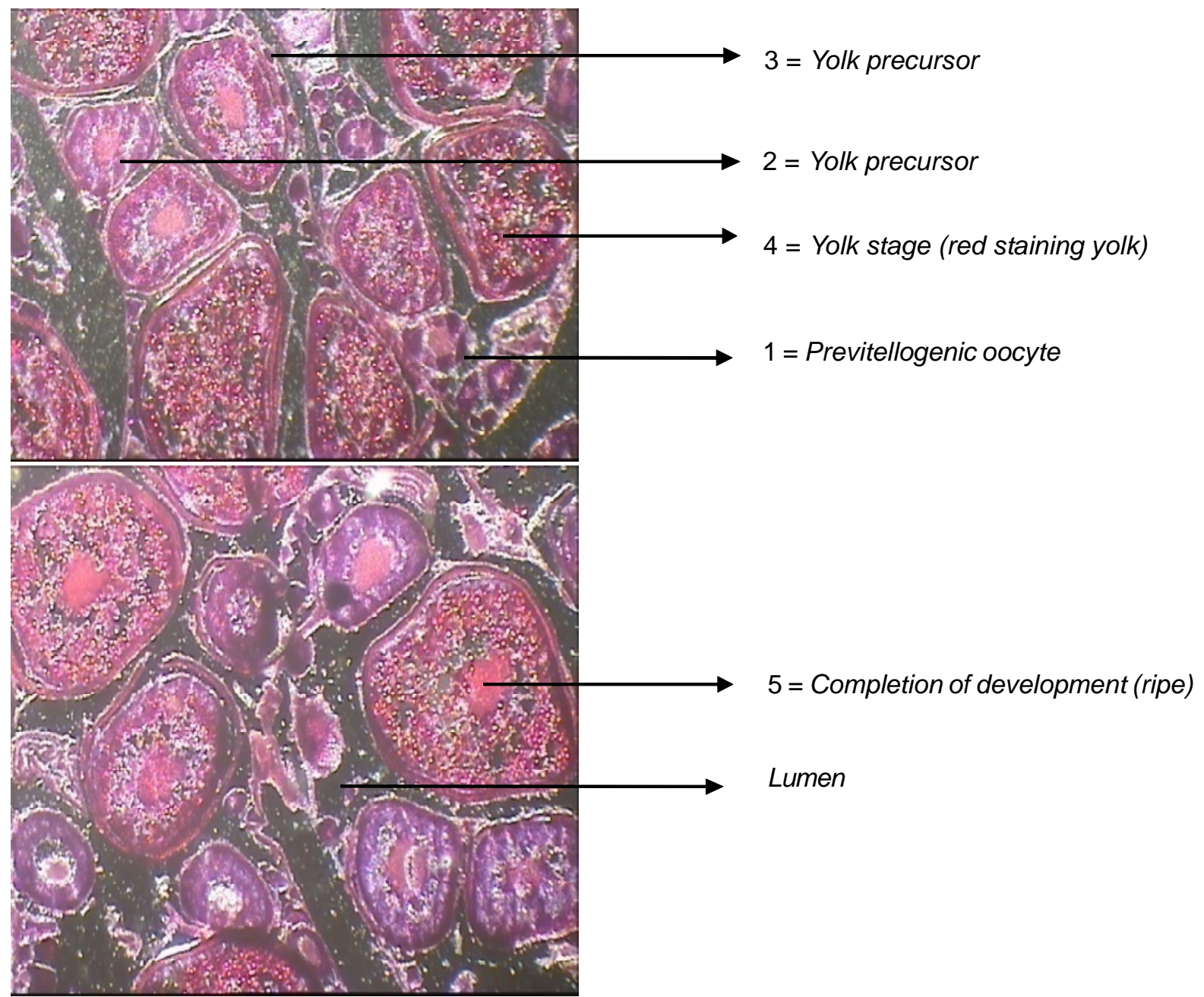

Gambar 4. Histologi gonad ikan kembung (Rastrelliger brachysoma) di pantai utara Jawa.

Figure 4. Gonad histology of short mackerel fish (Rastrelliger brachysoma) in coastal water of northern Java.

Tabel 1. Proporsi tingkatan gonad ikan kembung (Rastrelliger brachysoma) secara histologi di utara Jawa

Table 1. Gonad stage histology proportion of short mackerel fish (Rastrelliger brachysoma) in coastal water of northern Java

\begin{tabular}{|c|c|c|c|c|c|c|c|c|}
\hline No. & $\begin{array}{c}\text { Fork } \\
\text { length } \\
\text { (cm) }\end{array}$ & Stage & $\begin{array}{c}\text { Gonad } \\
\text { weight } \\
\text { (g) }\end{array}$ & $\begin{array}{c}\text { Previtellogenic } \\
\text { oocyte }\end{array}$ & $\begin{array}{c}\text { Yolk } \\
\text { precursor } 1\end{array}$ & $\begin{array}{c}\text { Yolk } \\
\text { precursor } 2\end{array}$ & Yolk stage & Completion \\
\hline 1 & 16,8 & 3 & 4,7 & 40 & 23 & 22 & 124 & 37 \\
\hline 2 & 16,7 & 3 & 3 & 32 & 28 & 29 & 49 & 45 \\
\hline 3 & 16,5 & 3 & 3,8 & 38 & 27 & 55 & 121 & 73 \\
\hline 4 & 17 & 3 & 4 & 52 & 50 & 66 & 126 & 69 \\
\hline 5 & 16 & 4 & 4,4 & 17 & 19 & 25 & 46 & 24 \\
\hline 6 & 17,2 & 3 & 3,4 & 31 & 21 & 21 & 83 & 47 \\
\hline 7 & 16,8 & 3 & 4,2 & 12 & 20 & 30 & 102 & 55 \\
\hline
\end{tabular}




\section{Dugaan Musim Pemijahan}

Pola fluktuasi bulanan gonado somatic index ikan dapat digunakan untuk menduga musim pemijahan ikan. Ikan kembung (Rastrelliger brachysoma) di pantai utara Pekalongan pada musim timur mempunyai nilai gonado somatic index rendah (minimum) dibandingkan dengan bulan-bulan lain. Penurunan nilai gonado somatic index ini terjadi sekitar bulan April sampai dengan Juli 2005 (Gambar 8). Penurunan nilai gonado somatic index tersebut dipertegas pada Gambar 9 dengan lebih dominan tingkat kematangan gonad I dan II pada bulan April sampai dengan Agustus. Ikan-ikan yang lebih matang banyak ditemukan pada musim barat. Menurut Suwarso \& Sadhotomo (1995), rendah nilai gonado somatic index tersebut dikarenakan kelompok ikan yang matang gonad tidak berada di daerah penangkapan (fishing ground), diduga bermigrasi ke daerah pemijahan (spawning ground) dan daerah penangkapan juga merupakan daerah untuk mencari makan (feeding ground) serta pertumbuhan bagi ikan ini. Suwarso \& Hariati (2003) juga menunjukkan bahwa terdapat indikasi pemijahan ikan kembung (Rastrelliger brachysoma) di perairan Indramayu dan Teluk Jakarta pada sekitar musim barat; gonad yang lebih besar (lebih matang) ditemukan di sekitar Teluk Jakarta.

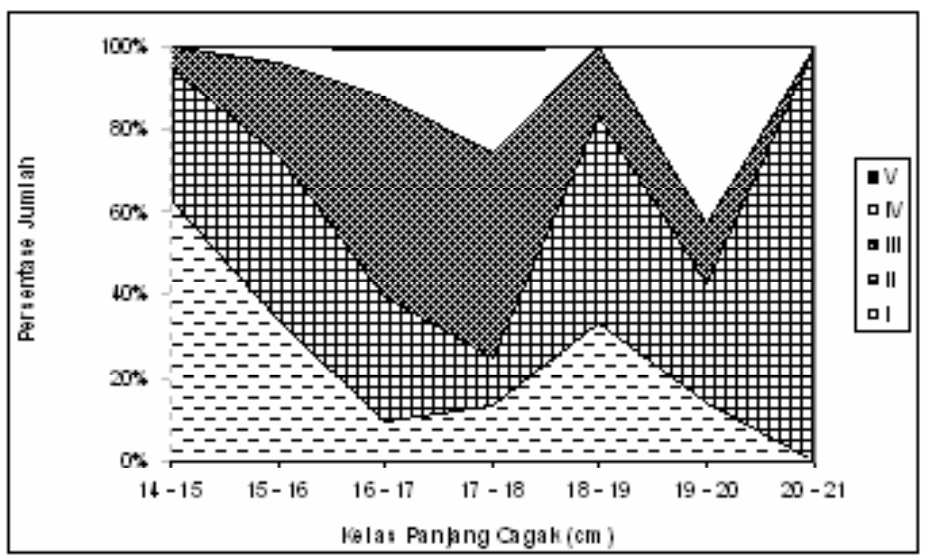

Gambar 5. Tingkat kematangan gonad ikan kembung (Rastrelliger brachysoma) berdasarkan pada ukuran panjang (FL).

Figure 5. Gonad stage of short mackerel fish (Rastrelliger brachysoma) by size (FL).

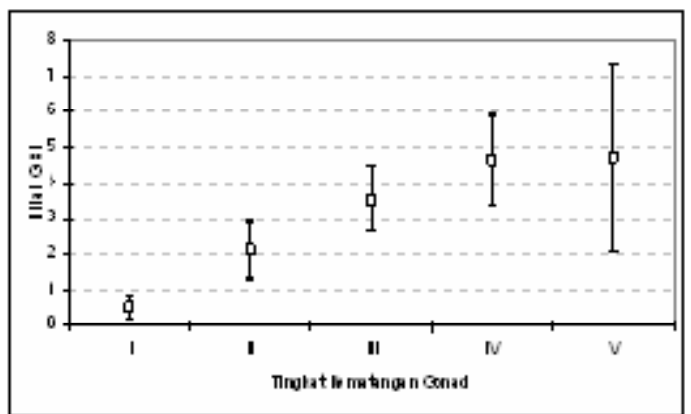

a

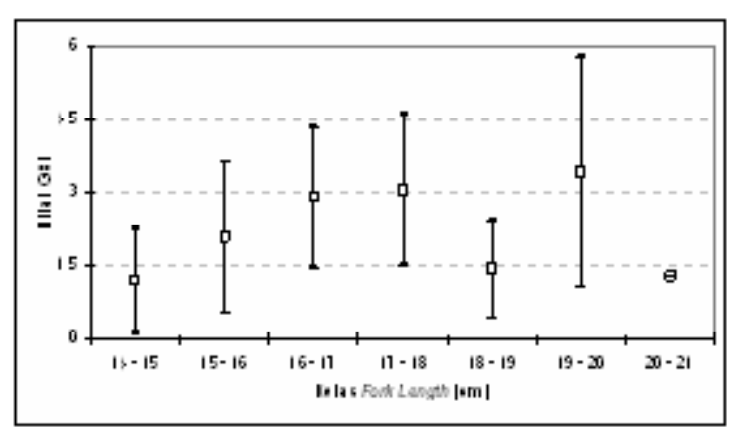

b

Gambar 6. Sebaran nilai gonado somatic index ikan kembung (Rastrelliger brachysoma) berdasarkan pada tingkat kematangan gonad (a) dan ukuran (b).

Figure 6. Gonado somatic index of short mackerel fish (Rastrelliger brachysoma) by gonad stage (a) and size (b).

\section{Genetik Ikan Kembung}

Hasil amplifikasi polymerase chain reaction dari genom mitochodrial-DNA ikan kembung (Rastrelliger brachysoma) dengan menggunakan primer 16A dan 16B mempunyai bobot molekul untai DNA $650 \mathrm{bp}$.
Template mitochodrial-DNA yang dihasilkan dari produk amplifikasi polymerase chain reaction kemudian dilakukan pemotongan dengan 5 enzim restriksi. Dari 5 enzim restriksi yang digunakan untuk memotong template mitochodrial-DNA, hanya 1 enzim yang tidak menghasilkan situs pemotongan, yaitu 
enzim Hind III. Sedangkan 4 jenis enzim yang lain (Alu I, Hae III, Nde II, dan Taq I) mempunyai situs pemotongan. Ke-4 enzim tersebut hanya mempunyai 1 pola restriksi atau pemotongan. Contoh hasil visualisasi restriksi DNA ikan kembung (Rastrelliger brachysoma) dapat dilihat pada Gambar 10. Karena hanya terdapat 1 pola restriksi, maka secara genotip tidak terdapat perbedaan yang nyata di antara 5 populasi yang diamati. Sehingga diduga bahwa selain ikan kembung (Rastrelliger brachysoma) mempunyai daerah sebaran yang luas, juga berasal dari stok yang sama. Dugaan lain, bahwa dimungkinkan terjadi genetic introgression atau pencampuran genetik sehingga memperlihatkan diversitas genetik yang rendah (low genetic diversity). Jika ikan kembung (Rastrelliger brachysoma) di pantai utara Jawa memang berasal dari stok yang sama, kemungkinan lokasi pemijahan juga di daerah yang sama. Karena rendah diversitas genetik, populasi yang sama dan sebaran yang luas, stok ikan kembung (Rastrelliger brachysoma) di sepanjang pantai utara Jawa sangat rawan terhadap aktivitas penangkapan dan kondisi lingkungan, misal polusi. Hal tersebut, dapat mengakibatkan suatu populasi mudah mengalami kepunahan, sehingga dalam pemanfaatan dan pengeloaan perikanan lebih rasional dan bijaksana serta dalam 1 unit pengelolaan, misal dengan pelarangan penangkapan ikan tersebut pada waktu tertentu untuk memberi kesempatan bereproduksi dan berkembang. Sedangkan populasi dengan keragaman genetik yang tinggi memiliki peluang hidup yang lebih baik. Hal ini, disebabkan karena setiap gen memiliki respon yang berbeda-beda terhadap kondisi lingkungan, sehingga dengan dimiliki berbagai macam gen dari individu-individu di dalam populasi, maka berbagai perubahan lingkungan yang ada akan dapat direspons lebih baik (Yusron, 2005). Penelitian mengenai struktur populasi genetik ikan kembung (Rastrelliger brachysoma) belum banyak dilakukan, tetapi penelitian serupa pernah dilakukan pada spesies ikan banyar (Rastrelliger kanagurta) pada tahun 2004 di India dengan membandingkan populasi ikan banyar (Rastrelliger kanagurta) di pantai timur dengan populasi di pantai barat India oleh Jayasankar et al. (2004); hasil menunjukkan bahwa tidak ditemukan perbedaan yang nyata antara populasi ikan banyar (Rastrelliger kanagurta) di pantai sebelah timur dengan pantai sebelah barat India.
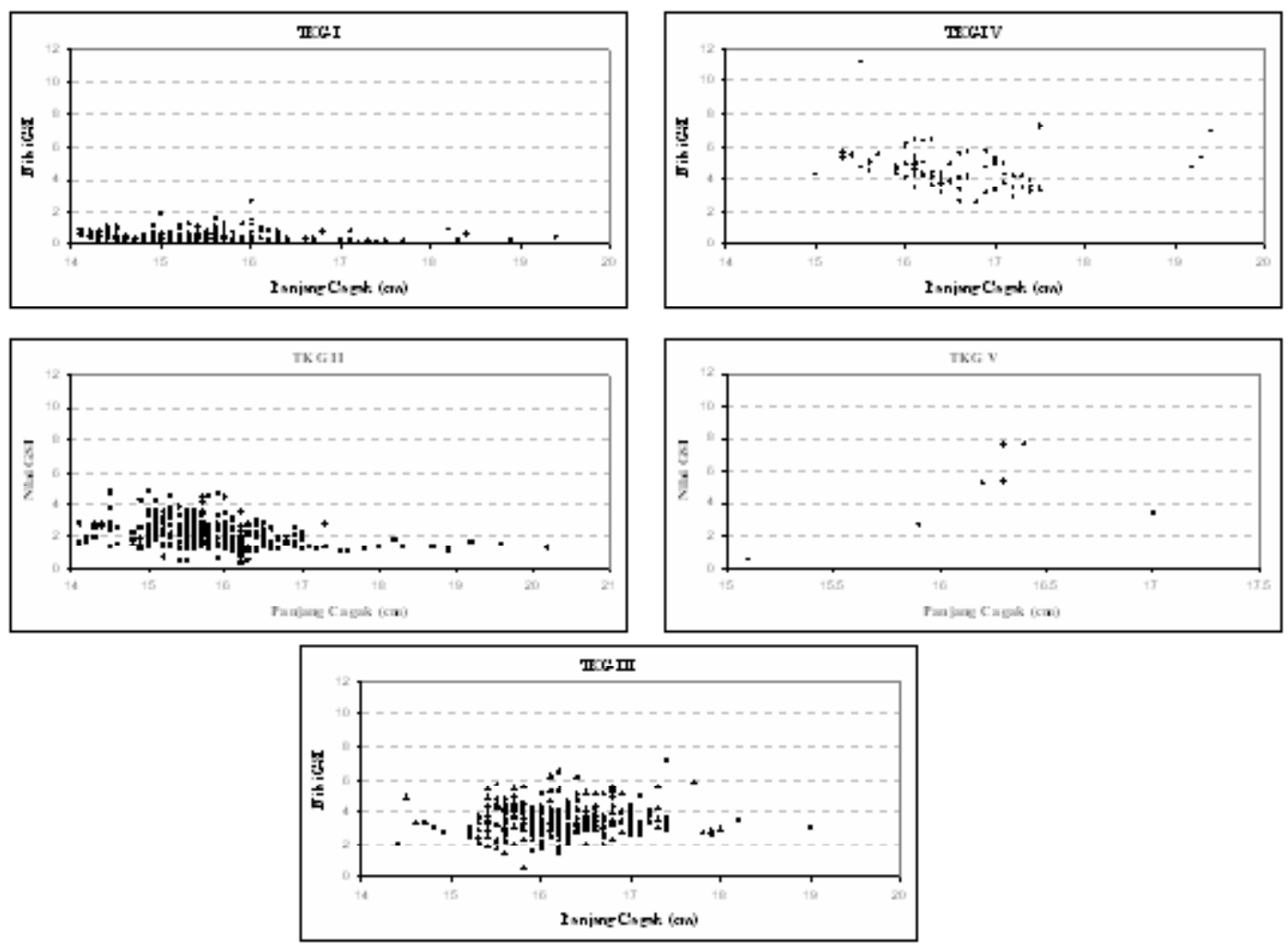

Gambar 7. Diagram scatter nilai gonado somatic index dari tiap tingkat kematangan menurut ukuran ikan kembung (Rastrelliger brachysoma).

Figure 7. Gonado somatic index scatter diagram from each gonad stage by size of short mackerel fish (Rastrelliger brachysoma). 


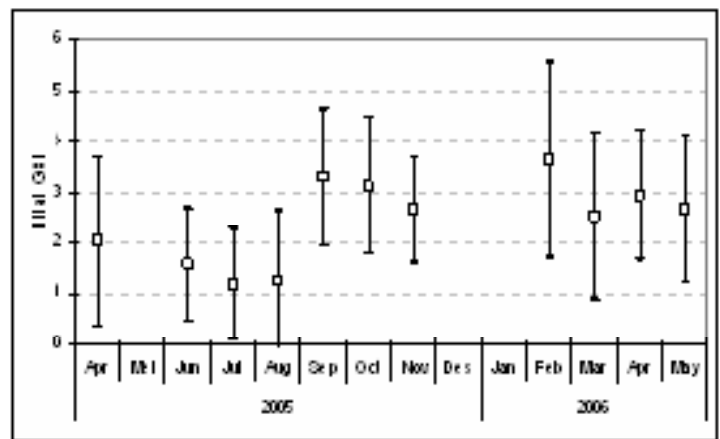

Gambar 8. $\quad$ Perubahan bulanan gonado somatic index ikan kembung (Rastrelliger brachysoma) di pantai utara Pekalongan.

Figure 8. Monthly gonado somatic index of short mackerel(Rastrelliger brachysoma) in coastal water of northern Pekalongan.

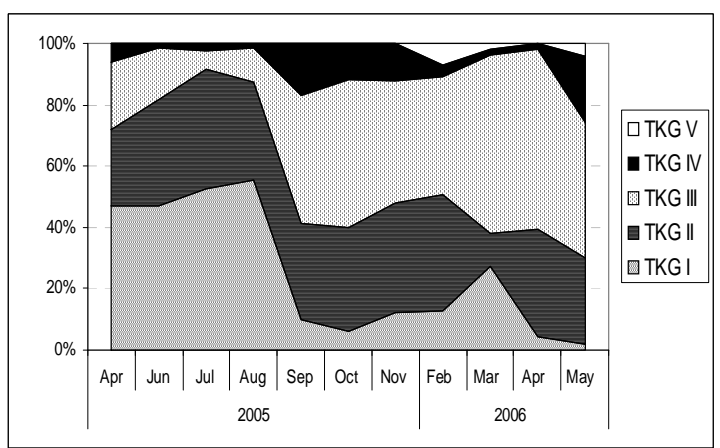

Gambar 9. Perubahan bulanan tingkat kematangan gonad ikan kembung (Rastrelliger brachysoma) di pantai utara Pekalongan.

Figure 9. Monthly gonad stage of short mackerel fish (Rastrelliger brachysoma) in coastal water of northern Pekalongan. 

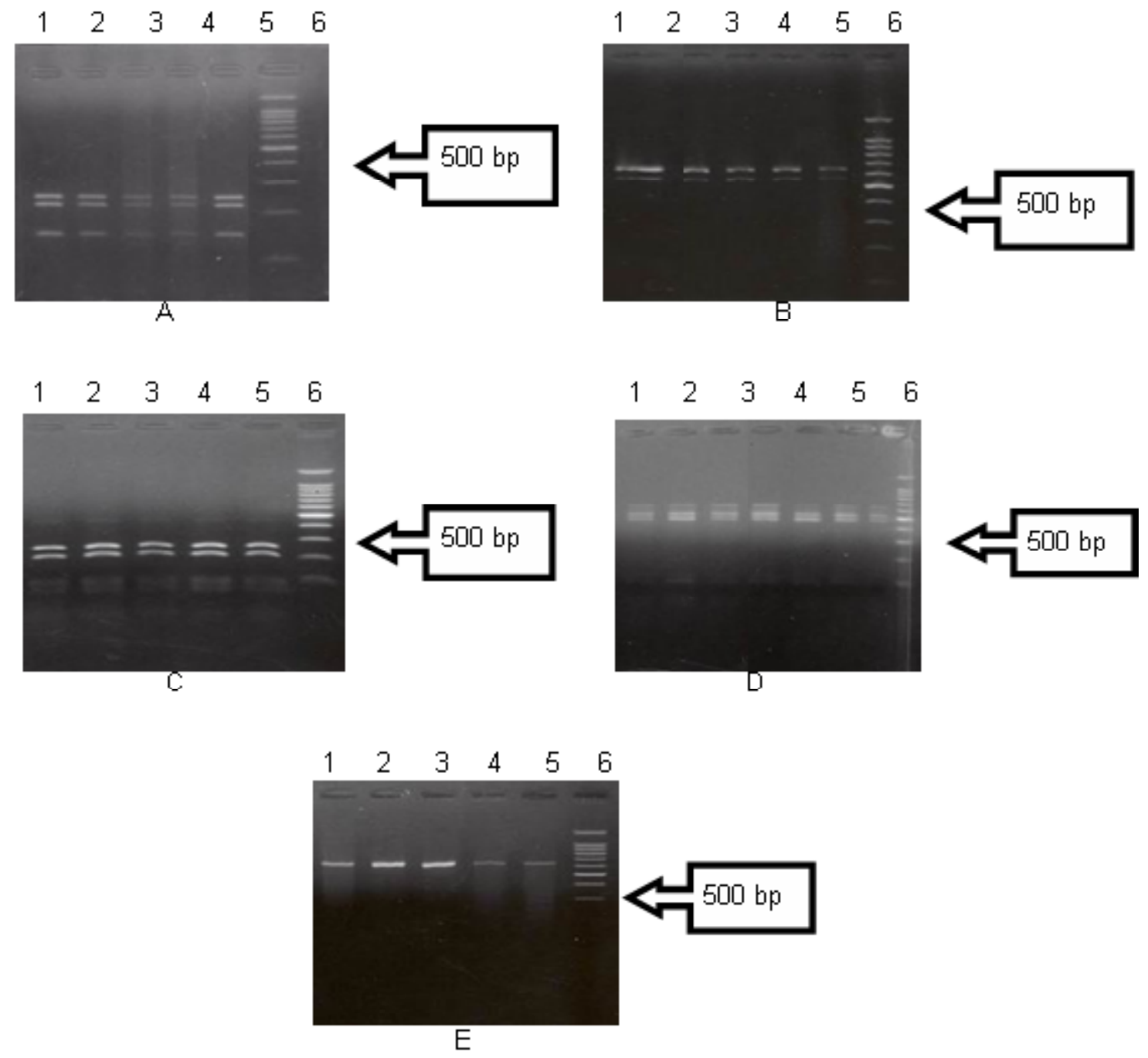

Gambar 10. Contoh visualisasi hasil restriksi mitochodrial-DNA ikan kembung (Rastrelliger brachysoma) di pantai utara Jawa-Selat madura: $\mathrm{A}=$ Alu I, $\mathrm{B}=$ Hae III, C = Nde II, D = Taq I, E = Hind III, $1=$ Jakarta, 2 = Eretan Wetan, $3=$ Pekalongan, $4=$ Rembang, $5=$ Pasuruan, dan $6=$ Marker.

Figure 10. Picture from short mackerel's (Rastrelliger brachysoma) mitochodrial-DNA restriction result in coastal water of northern Java-Madura strait: $A=$ Ali I, $B=$ Hae III, $C=$ Nde II, D = Taq I, $E=$ Hind III, 1 = Jakarta, $2=$ Eretan Wetan, $3=$ Pekalongan, $4=$ Rembang, $5=$ Pasuruan, and $6=$ Marker.

Tabel 2. Distribusi frekuensi haplotipe dari beberapa populasi ikan kembung (Rastrelliger brachysoma) di pantai utara Jawa berdasarkan pada mitochodrial-DNA D-loop yang direstriksi oleh 4 jenis enzim renstriksi

Table 2. Haplotype frequency distribution of some short mackerel fish population (Rastrelliger brachysoma) in coastal water of northern Java base on mitochodrial-DNA D-loop restricted by 4 restrictor enzymes

\begin{tabular}{lccccc}
\hline \multicolumn{1}{c}{ Haplotipe } & Jakarta & Indramayu & Pekalongan & Rembang & Pasuruan \\
\hline AAAAA & 1 & 1 & 1 & 1 & 1 \\
N-contoh & 9 & 9 & 9 & 9 & 9 \\
N-haplotipe & 1 & 1 & 1 & 1 & 1 \\
Diversitas genetik & 0 & 0 & 0 & 0 & 0 \\
\hline
\end{tabular}




\section{KESIMPULAN}

Beberapa kesimpulan yang dapat diambil dari penelitian ini adalah bahwa perbandingan rasio jenis kelamin ikan kembung (Rastrelliger brachysoma) jantan dan betina tidak berbeda nyata dengan perbandingan 1:1. Contoh ikan kembung (Rastrelliger brachysoma) yang tertangkap di daerah penangkapan pada umumnya ( $91 \%$ ) berada dalam kondisi yang belum matang (immature = tingkat kematangan gonad I, II, dan III). Nilai gonado somatic index ikan kembung (Rastrelliger brachysoma) tersebar tidak beraturan karena ada variasi dari bobot gonad pada suatu kelompok ikan. Nilai gonado somatic index cenderung semakin besar dengan semakin bertambah panjang dan tingkat kematangan gonad ikan. Ukuran reproduktif ikan kembung (Rastrelliger brachysoma) yang sudah matang tingkat kematangan gonad IV) terdapat pada kisaran panjang antara 19 sampai dengan $20 \mathrm{~cm}$ FL, dengan nilai gonado somatic index antara 0,49 sampai dengan 6,98. Diduga musim pemijahan ikan kembung (Rastrelliger brachysoma) terjadi pada musim timur. Tidak terdapat perbedaan genetik yang nyata antara ikan kembung (Rastrelliger brachysoma) dari 5 lokasi penangkapan ikan yaitu perairan utara Jakarta, Eretan Wetan (Indramayu), Pekalongan, Rembang, dan Pasuruan (Selat Madura), karena hasil analisis menunjukkan hanya terdapat mempunyai 1 pola restriksi atau pemotongan. Karena stok ikan kembung (Rastrelliger brachysoma) di utara Jawa adalah sama, maka diperlukan pemanfaatan dan pengelolaan perikanan dalam 1 unit pengelolaan.

\section{UCAPAN TERIMA KASIH}

Penulis mengucapkan terima kasih pada Dr. Estu Nugroho, Kepala Balai Riset Budi Daya Air Tawar (Sempur, Bogor) atas bimbingan dan dukungan sarana dalam analisis contoh beserta interpretasi. Terima kasih juga disampaikan untuk Prihatiningsih, S.Pi. dan Nurwiyanto yang telah membantu dalam preparasi histologi gonad.

\section{PERSANTUNAN}

Kegiatan dari hasil riset perubahan upaya, hasil tangkapan, dan biologi reproduksi ikan pelagis kecil di Laut Cina Selatan dan Selat Makassar, T. A. 20052006, di Balai Riset Perikanan Laut, Muara BaruJakarta.

\section{DAFTAR PUSTAKA}

Atmaja, S. B., B. Sadhotomo, \& Suwarso. Reproduction of the main small pelagic species.
In M. Potier \& S. Nurhakim (1994), Biology, Dynamics, and Exploitation of the Small Pelagic Fishes in the Java Sea. 69-84.

Carvalho, G. R. \& T. J. Pitcher. 1995. Molecular genetics in fisheries. Chapman \& Hall. London. $255 \mathrm{pp}$.

Holden, M. J. \& D. F. S Raitt (eds.). 1974. Manual of fisheries sciences. Part 2. Methods of Resource Investigation and Their Application. FAO Fish. Tech. Pap. 115 (Rev. 1). 1-214.

Isa, M. M., R. Rumpet, S. A. S. A. Kadir, S. Ishikawa, \& S. Siriraksophon. 2002. Standard operating procedures for pilot data and analysis. Southeast Asian Fisheries Development Centre Marine Fishery Resources Development and Management Department.

Jayasankar, P., P. C. Thomas, M. P. Paulton, \& J. Mathew. 2004. Morphometric and genetic analyzes of Indian Mackerel (Rastrelliger kangurta) from Peninsular India. Asian Fisheries Science. 17: 201215.

Martin, A. P., R. Humphreys, \& S. R. Palumbi. 1992. Population genetic structure of the armorhead, Pseudpentaceros wheeleru, in the North Pacific Ocean: Application of the polymerase chain reaction to fisheries problems. Canadian Journal Fisheries Aquatic Science. 49. 2,386-2,391.

Nugroho, E., M. Takagi, \& N. Taniguchi. 1997. Practical manual on detection of DNA polymorphism in fish population study. Bulletin of Marine Science and Fisheries. Kochi University. 17. 109-130.

Nurhakim, S. 1993. Beberapa aspek reproduksi ikan banyar (Rastrelliger kanagurta) di perairan Laut Jawa. Jurnal Penelitian Perikanan Laut. 81. 8-20.

Park, L. K. \& P. Morgan. 1995. Developments in molecular genetic techniques in fisheries. In Molecular Genetics in Fisheries by Carvalho, G. R. \& Pitcher, T. J. (Eds.) Chapman \& Hall. London. $1-28$.

Potier, M. \& B., Sadhotomo. 1991. Sampling training. ALA/INS/87/17. Scien. And Tech. Doc. 4. 29 p.

Sujastani, T. 1976. The species of Rastrelliger in the Java Sea, Their Taxonomy and Morphometry 
(Perciformes, Scombridae). Marine Research In Indonesia. No.16. 1-29.

Sukendi. 2001. Biologi reproduksi dan pengendaliannya dalam upaya pembenihan ikan baung (Mystus nemurus) dari perairan Sungai Kampar, Riau. Disertasi Program Pasca Sarjana. Institut Pertanian Bogor. Bogor.

Suwarso \& B. Sadhotomo. 1995. Perkembangan kematangan gonad ikan bentong Selar crumenophthalmus (Carangidae) di Laut Jawa. Jurnal Penelitian Perikanan Indonesia. 02. 77-88.

Suwarso \& T. Hariati. 2003. Biologi dan ekologi ikan pelagis kecil di pantai utara Jawa Barat dan Selat Sunda. Jurnal Penelitian Perikanan Indonesia. Vol.9 No.7. 29-36.
Suwarso, M. Taufik, A. Zamroni, U. Chodriyah, \& W. A. Pralampita. 2007. Laporan teknis kegiatan riset perubahan upaya, hasil tangkapan dan biologi populasi ikan pelagis kecil di Laut Cina Selatan, Laut Jawa, dan Selata Makassar. Balai Riset Perikanan Laut. Jakarta.

Ward, R. D. \& P. M. Grewe. 1995. Appraisal of molecular genetic techniques in fisheries, In Molecular Genetics in Fisheries by Carvalho, G. R. \& Pitcher, T. J. (Eds.) Chapman \& Hall. London. 55-80.

Yusron, E. 2005. Pemanfaatan keragaman genetik dalam pengelolaan sumber hayati laut. Oseana. Vol.30 No. 2. 29-34. 
Lampiran1. Deskripsi tingkat kematangan gonad ikan Kembung (Rastrelliger brachysoma) (Isa et al., 2002)

Appendix 1. Description of gonad maturity stage for short mackerel fish(Rastrelliger brachysoma) (Isa et al., 2002)

\begin{tabular}{|c|c|c|}
\hline $\begin{array}{c}\text { Tingkat } \\
\text { kematangan gonad } \\
\text { (Maturity stage) }\end{array}$ & $\begin{array}{l}\text { Status } \\
\text { (State) }\end{array}$ & $\begin{array}{c}\text { Deskripsi } \\
\text { (Description) }\end{array}$ \\
\hline 1 & $\begin{array}{c}\text { Dara } \\
\text { (immature) }\end{array}$ & $\begin{array}{l}\text { Ovary dan testis kecil padat, menempel dekat lubang anus, bentuk } \\
\text { silindris. Ovary berwarna kemerahan jernih, transiucent; testis } \\
\text { keputihan. Seringkali tertutup lemak. Gonado somatic index. } 0,11 \\
\text { sampai dengan } 2,69 \text {. }\end{array}$ \\
\hline$\|$ & $\begin{array}{c}\text { Perkembangan } \\
\text { (Maturing) }\end{array}$ & $\begin{array}{l}\text { Ovary dan testis ukuran sampai dengan } 1 / 2 \text { panjang rongga } \\
\text { badan. Ovary kemerahan jernih, testis putih; kira-kira simetris. } \\
\text { Butiran ova tidak nampak oleh mata telanjang. Gonado somatic } \\
\text { index. } 0,28 \text { sampai dengan } 4,75 \text {. }\end{array}$ \\
\hline III & $\begin{array}{l}\text { Pematangan } \\
\text { (Ripening) }\end{array}$ & $\begin{array}{l}\text { Ovary dan testis ukuran } 1 / 2 \text { sampai dengan } 2 / 3 \text { panjang rongga } \\
\text { badan. Ovary berwarna kuning-kemerahan, terlihat jelas butiran- } \\
\text { butiran telur, nampak pembuluh darah pada permukaan; testis } \\
\text { berwarna putih. Tidak ada telur transparan atau transilucent. } \\
\text { Gonado somatic index. } 0,59 \text { sampai dengan } 7,19 \text {. }\end{array}$ \\
\hline IV & $\begin{array}{c}\text { Matang } \\
\text { (Mature/ripe) }\end{array}$ & $\begin{array}{l}\text { Ovary dan testis besar ukuran } 2 / 3 \text { sampai dengan memenuhi } \\
\text { rongga badan. Ovary berwarna orange-pink dengan banyak } \\
\text { pembuluh darah, transparan; butiran ova besar, ripe, dan } \\
\text { transiucent. Testis putih, lembek. Gonado somatic index. } 2,59 \\
\text { sampai dengan } 11,24 \text {. }\end{array}$ \\
\hline$V$ & $\begin{array}{c}\text { Mijah/salin } \\
\text { (Spent) }\end{array}$ & $\begin{array}{l}\text { Ovarium dan testis berukuran sampai dengan } 1 / 2 \text { dari panjang } \\
\text { rongga badan. Dinding-dinding meluruh. Ovary berisi sisa } \\
\text { hancuran buram dan telur yang matang, gelap, atau transparan. } \\
\text { Testis berwarna darah and lembek. Gonado somatic index. } 0,53 \\
\text { sampai dengan } 7,73 \text {. }\end{array}$ \\
\hline
\end{tabular}

